\title{
Bácskai, Éva. 2018. Századok hullámain: Egy szegedi zsidó család letelepedésének története. ['On the Waves of Centuries: The History of the Settling of a Jewish Family in Szeged']. Szeged: Oriold és Társai. 357 pp.
}

\author{
Reviewed by Dávid Szőke ${ }^{1}$, University of Szeged
}

Éva Bácskai's book Századok hullámain ['On the Waves of Centuries'] chronicles the history of the author's family for the last two centuries. The result of an extensive research, this book portrays the everyday life of a family in Szeged within a wider historical context from the viewpoint of the second-generation survivors of the Holocaust of Hungarian Jews. The author's intent is to incorporate the family's legacy into the European memory-culture and to create a solidarity-based common historical consciousness. By doing so, she revisits some of the key historical moments of Szeged's Jewish population, such as their participation in the 1848-1849 Revolution, their involvement in the rescue during the great flood of 1879 and their assistance to building out the city's present image. Sorrowfully, in the book's concluding chapters all these efforts and enterprises are shadowed by the haunting depiction of the Holocaust of the city's Jews. The book is significant not merely for its attempt to record the struggle of the writer's family to survive history but because it draws attention to an intercultural understanding that is based on mutual respect, recognition and appreciation. Through its energetic narrative it provides a remarkable insight into how much the Jewish community of Szeged has contributed to the design and preservation of the architectural and cultural values of the city, and how all their creativity and humanity were lost during the Holocaust.

The book is described by its author as a "documentary novel," thus adapting to the multitude of narratives under the genre definition of "life-writing" that transcend the borders amongst historical fact, biography and fiction. This way the book avoids being a mere historical account of events, and through its personal storytelling it maintains a balance between the public and the private. With this narrative technique, the author creates a link between the reader and the characters of the book, involving the reader in the story of her ancestor Seifmann and Winter families. Maintaining a retrospective line of narration to create a traditional biographical account, the book emphasizes the continuity of life. Despite the tragedies and traumas undergone by the author's family, the book's strength lies in its emphasis on survival and in its confidence that recovery is attainable. This message is articulated in the preface of the book, where the author draws the reader's attention to the importance of memory through speech and raises awareness of

${ }^{1}$ beszelo86@gmail.com

$($ (c) $)$ EY

UILIS D-Sent?
New articles in this journal are licensed under a Creative Commons Attribution 4.0 International License.

This journal is published by the University Library System of the University of Pittsburgh as part of its D-Scribe Digital Publishing Program and is cosponsored by the University of Pittsburgh Press 
Szőke, Dávid. “Bácskai, Éva. 2018. Századok hullámain: Egy szegedi zsidó család letelepedésének története. ['On the Waves of Centuries: The History of the Settling of a Jewish Family in Szeged']. Szeged: Oriold és Társai. 357 pp." Hungarian Cultural Studies. e-Journal of the American Hungarian Educators Association, Volume 12 (2019) DOI: 10.5195/ahea.2019.378

the respect for other cultures. By this, the narrative sets the stories of Holocaust-survivor Jewish families into a wider discourse and provides the opportunity to reassess different cultural and religious identities constantly evolving in the history of this city as elsewhere.

Bácskai's book is divided into three main parts. The introductory first part recounts the author's personal engagement with her family history. Here the author describes her research and efforts to make this history viable, and her aspiration to knock down cultural and religious conflicts based on prejudice. In so doing, she stresses that throughout their shared history Jews and Hungarians lived together in friendly terms and Jews always sided with and fought alongside Hungarians in their centuries-long struggle for independence. The second part reveals the history of the Seifmann family, the author's ancestral family of traders and industrial entrepreneurs, their moving to Szeged from the Slovakian village Hanusfalva, their struggle with other small and big business entrepreneurs, and their life during and after the 1848-1849 Revolution to the end of the nineteenth century. While this family chronicle follows a Jewish upper middle-class family's typical course of social integration and participation in the city's development, for several lines it also recalls such major all-Hungarian historical figures such as Ferenc Deák, Lajos Kossuth, István Tisza and the Austrian emperor Franz Joseph I. Moreover, with the help of black-andwhite illustrations, here the book recollects the city's history, its little shops, palaces, squares, pedestrian streets, old synagogue and culture houses.

The book's third part depicts the horrors of the twentieth century from the early 1900s to the end of the Second World War as experienced by the Jews of Szeged and focusing on the author's family. It powerfully explains how the city and the country that had given home to many Jewish families for nearly two centuries now rejected them by the force of mega historical events and political powers that eventually resulted in the extermination of the majority of the country's Jews. A particularly harrowing segment of this part is its step-by-step description of how the country's and city's Jews were gradually deprived of their civil and human rights starting with the dismissal of intellectuals from universities and educational institutions, continuing with the withdrawal of their radio and pharmacy licenses, through the confiscation of their properties and leading to their persecution and annihilation. The suffering and traumatic experiences of the Winter family in 1944-5 are described with a dramatic force, stressing their enduring perseverance until the final moment of liberation. This part pays special tribute to the actions of the "Vaad" [Heb. 'committee'], meaning the Jewish Rescue Committee of the Jewish Agency that through negotiations with the Nazis managed to change the destination and destiny of a transport of Szeged Jews from Auschwitz to the Austrian Strasshof transit camp and thus saved them from immediate destruction.

Interestingly, the genesis of the book is summed up in its epilogue where the author gives voice to her determination to preserve memory and expresses respect for her ancestors by conveying their ultimate message to younger generations. As she claims, she sees it her task as a writer to pass on these stories she has known only by hearing. This objective is further amplified and expanded by her making a tribute to the family's victims of both the First and the Second World War and by perpetuating their names and photographs in her book, as well as by her thorough outlining of her family tree in its closing pages.

Éva Bácskai's documentary novel is of vital contribution because it not only serves as an outstanding historical sociography but also echoes the need of the second generation of Holocaust survivors to redeem their ancestors out of oblivion and obscurity. The necessity of this 
Szőke, Dávid. "Bácskai, Éva. 2018. Századok hullámain: Egy szegedi zsidó család letelepedésének története. ['On the Waves of Centuries: The History of the Settling of a Jewish Family in Szeged']. Szeged: Oriold és Társai. 357 pp." Hungarian Cultural Studies. e-Journal of the American Hungarian Educators Association, Volume 12 (2019) DOI: 10.5195/ahea.2019.378

latter argument is confirmed by the fact that nowadays there are fewer survivors left with us to tell their family stories and ordeal of persecution and eventual survival. This task falls on their descendants, whose demand is that their family and Holocaust (hi)story be part of the current cultural, social, and political reality of present-day Hungary and Europe, because and in the face of newly growing anti-Semitism and other extreme political ideologies. Consequently, beside the point that with its lively descriptions and illustrations of old Szeged this book provides both aesthetical and emotional joy for those living in or knowing the city, it also relates (to) the Holocaust not as a past historical event but rather as a part of the city's and the country's social, political and cultural existence and identity. With its scope, this book makes the concepts of trauma and memory part of a common memory-culture as it teaches us to learn the disastrous lesson of the Shoah and respect our differences. 